InOdia $\quad \begin{aligned} & \text { InMedia } \\ & \text { The French Journal of Media Studies }\end{aligned}$

$2 \mid 2012$

Performing/Representing Male Bonds

\title{
Performing/Representing Male Bonds
}

Raphael Costambeys-Kempczynski, Claire Hélie and Pierre-Antoine Pellerin

\section{(2) OpenEdition}

\section{Journals}

Electronic version

URL: http://journals.openedition.org/inmedia/451

DOI: 10.4000/inmedia.451

ISSN: 2259-4728

\section{Publisher}

Center for Research on the English-Speaking World (CREW)

Electronic reference

Raphael Costambeys-Kempczynski, Claire Hélie and Pierre-Antoine Pellerin, « Performing/

Representing Male Bonds », InMedia [Online], 2 | 2012, Online since 16 April 2013, connection on 10 December 2020. URL : http://journals.openedition.org/inmedia/451 ; DOI : https://doi.org/10.4000/ inmedia.451

This text was automatically generated on 10 December 2020.

(C) InMedia 


\title{
Performing/Representing Male Bonds
}

\author{
Raphael Costambeys-Kempczynski, Claire Hélie and Pierre-Antoine \\ Pellerin
}

\section{EDITOR'S NOTE}

This dossier was followed for InMedia by Divina Frau-Meigs and Nolwenn Mingant.

\section{Masculinity, Men, Male}

1 In 1993, Michael S. Kimmel published a ground-breaking article entitled "Invisible Masculinity," which began with a particularly striking opening statement: "American men have no history." Kimmel argues that even if history books are largely written by men and are about men, they do not deal with the experience of men as men. Thus, for Kimmel, men have no history as "gendered selves" and the effect is to render the multiplicity of masculine identities invisible. Thanks to the work of feminist scholars over the past four decades we have been able to recognize the different manifestations of invisible hegemonic masculinities. As Stephen M. Whitehead informs us, the fields of Masculinity and Men's Studies have thus been able "to turn attention to men in a way that renders them and their practices visible, apparent and subject to question." ${ }^{2}$

2 Rather than attach themselves to hegemonic masculinity as a unified normative practice guaranteeing men's domination over women, the articles in this issue of InMedia will attempt to render visible some of the practices that construct and define the various relationships between men as well as structure the homosocial spaces in which they take place. Concentrating on the performances of masculinity, the articles featured here focus on the representations made of male bonds in and through different media in the English-speaking world. Though the notion of 'performance' here is to be understood as both the observable behaviour of one group of people as 
well as the carrying out of an operation that has been commanded, one must also bear in mind Judith Butler's notion of gender performativity. Butler distinguishes between performance and performativity where "gender proves to be performative - that is constituting the identity it is purported to be. In this sense, gender is always a doing, though not a doing by a subject who might be said to pre-exist the deed." ${ }^{3}$ For Butler, gender is "a set of repeated acts within a highly rigid regulatory frame" ${ }^{4}$ where the subject, masculine or feminine, is not free to choose the performance of their gender because the subject only exists within performative gender acts. The articles collected here deal both with Butler's understanding of gender identity but also with media representations of the performances of masculine subjects and how these are received by different communities of men, whether it be actors in film, male models on the covers of men's magazines, online avatars or singers on a stage.

3 It is important at this point to map out the vocabulary used when discussing masculinity. Defined as the "qualities regarded as characteristic of men", ${ }^{5}$ the simple denotation of the noun 'masculinity' does not preclude its application to women. ${ }^{6}$ There is a suggestion in this dictionary definition, however, that if a subject does not demonstrate masculine qualities it would be difficult to identify it as a man. The state of being a man and having masculine characteristics appears inextricably linked as R.W. Connell confirms:

4 In its modern usage the term assumes that one's behaviour results from the type of person one is. That is to say, an unmasculine person would behave differently: being peaceable rather that violent, conciliatory rather than dominating, hardly able to kick a football, uninterested in sexual conquest, and so forth. ${ }^{7}$

5 It is the definition of the characteristics of men, that is to say the quality of men as societal and cultural beings, which must retain our attention. In the precise context of male bonds, the articles featured here also tackle the question of men as social beings defined by and through their associations with other men.

6 The adjective 'male' refers us back to a purely biological notion designating the sex that can fertilize the opposite sex but cannot bear offspring itself. ${ }^{8}$ Yet, as we continually swim against the current of connotation, it is impossible for such a term to remain impervious to suggestion, inference and interpretation. In this manner, to be male is to be robust, vigorous and virile; it is, of course, to be 'manly'. Beyond grouping together these attributes, however, such terms as 'maleness' and 'manliness' are meant to help constitute an identifiable group, a group that can position itself in an 'us against them' logic wrapped up in such dictionary definitions as "the type of strength, fortitude, or hardiness traditionally associated with men as opposed to women or children" 9 (our italics).

7 It is important to analyse dictionary definitions as they often remain the primary source of information when trying to stabilise the meaning of words. However, as we have seen these definitions are not thorough enough when trying to understand the social and cultural impact generated by such complex terminology. The articles published in this issue of InMedia address, with vital critical insight, these difficult and intricate notions through the links and ties that constitute different communities of men. These male bonds are understood to be complex societal phenomena that function as part of an integral whole, not in opposition to but in relation with women as well as other men and groups of men. 


\section{Why Study Men and Masculinities?}

8 Like femininity, masculinity is an exclusion procedure, a code that protects us against individualism and the expression of freedom of others. Where speakers violate these codes the system traditionally reacts by categorizing non-masculine behaviour in men as pathological, obscene, perverse, deviant or simply criminal. Thus, as Donald E. Hall remarks, the system must work to police against such behaviour: "[ $t]$ he prevailing gender and sexual paradigms of an era regulate everyone's lives, working to curtail possibilities and relentlessly push sexual/erotic relationships into socially acceptable channels." 10

9 Masculinity and femininity it follows are second order codes, special categories of political fiction operating at the level of the social system. Second order codes are organic, however, bent on being all-inclusive, and gradually non-masculine behaviour is subsumed and ingested by what one may wish to call hegemonic masculinity.

10 As the American historian E. Anthony Rotundo reminds us: "Manhood is not a social edict determined on high and enforced by law. As a human invention, manhood is learned, used, reinforced, and reshaped by individuals in the course of life."11 Moreover, if men can subvert rules by virtue of their cognitive autonomy, they can push back the boundaries of masculinity, of what is socially acceptable for a man to say or do without compromising his identity as a man. Nick Growse's article presented here examines how British men's magazines today tackle issues that had long been perceived as feminine concerns by the British press such as parenting and health. At the same time, Growse demonstrates how these magazines also reject traditional heroic forms of athletic masculinity which their readership appears to view as 'unmanly'. Chris Tinker's article on 1980s male pop singers shows how new forms of masculine identity become acceptable through performances that revolve around sensitivity and androgyny, feminizing a musical tradition that had so far relied more or less exclusively on virile and even aggressive performances.

11 Through the evolution of different media representations, the extension of what masculine is and the way we understand masculine identities change over time. Along with the question 'What is it to be masculine?' comes its phenomenal bedfellow: 'What is it to be perceived as masculine?' In other words, masculinity as a cognitive fiction, or gender script, participates in the construction of reality at the self-referential and the hetero-referential levels. Its function lies in the communication of socially useful codifications between men and women but also amongst men themselves. The media has played an important role in producing and reproducing masculine gender scripts, especially the media directed at a male audience such as men's magazines which are dominated by articles written by men about men for men. Like discourses that construct our understanding of history, religion, the law, science, politics, philosophy, etc., we must recognise that masculinity is itself a masculine construct. As Connell stresses, the study of this systematic authoritarian "hegemonic masculinity" becomes essential in understanding how the world around us has been fashioned. ${ }^{12}$

12 Like all other second order codes, masculinity is governed by a number of societal rules; it is a heteronomy. What place then is left to the autonomy of authenticity, of staying true to oneself, of legislating one's self? This question is central in understanding the heuristic fiction of masculinity. For Stefan Dudink therein lies a paradox that it is important to address, where "men adhering to these norms and 
expectations can at the same time live in a nearly untouchable aura of individuality, in a powerful fiction of just being themselves." ${ }^{13}$ Moreover, if social contexts change and mutate over time, then so too must the heuristic fiction of masculinity. Indeed, if we conceive of the possibility that several social contexts can co-exist, so then must we conceive of the possibility of several masculinities co-existing. Once gender theory had understood this, it could challenge these fictions by defining and redefining them, as Hall writes:

13 Key then to gender theory of the late twentieth and early twenty-first century is a meta-commentary on such contextual embeddedness and 'arbitrariness' which allows the gender theorist and political activist to challenge discriminatory laws, popular perceptions and offensive discursive commonplaces. All such theoretical categorisations and their at once enabling and resulting (or, in other words, selfreinforcing) lived, interpersonal systems of behavior became newly perceived as socially constructed and therefore potentially deconstructable through concerted analytical work and political action. ${ }^{14}$

If, as we have argued, there is not one but many co-existing and conflicting masculinities, if gender is a fiction, a cultural construct, then it is contingent and is open to perpetual redefinition. Thus, studying men and masculinities, as constituting a series of discrete groups must be understood as vital.

\section{Crisis of Masculinity}

15 According to Hélène Cixous, feminist critical theory has come to threaten the stability of masculinity. ${ }^{15}$ Indeed, the development of feminist criticism and gender theory appears to have led to a proliferation of literature on the disruption of masculinity and the success of such publications as psychiatrist Pr. Anthony Clare's On Men: Masculinity in Crisis $^{16}$ (2000) bears witness to this. In his book, he begins by addressing the phallic question of masculine insecurity: "Male preoccupation with their penises would appear to be based on fear, right enough: not on the Freudian fear of castration, but on the Alderian fear of ridicule. Are we up to it? ask today's men anxiously, peering at their shrivelled cocks and analysing their social skills [...]." ${ }^{17}$

"Are we up to it?" The rhetorical nature of such a question underscores the selfreflexive nature of masculinity, which projects masculine qualities as defined by men onto the male subject. According to Clare, the sense of ridicule to which he alludes has a dual origin: men performing their hypermasculine role on the one hand, and women ridiculing men's obsession with the size of their penises on the other. For sociologist William Simon, the fear of castration hides a number of anxieties that "can also serve as a defence against one's hostility towards one's own penis, as a metaphor for a complex array of anxieties regarding shifting expectations and uncertain futures." ${ }^{18}$ It is within these "shifting expectations and uncertain futures" that a sense of crisis is born.

17 Simon understands one aspect of the fear of castration as developing from the bonds that tie masculinity to a sense of belonging to a particular social class; thus the homosocial comes to play a fundamental role. For instance, if the working class struggle was often seen to be a male specific struggle, a man who aspired to social or professional mobility would find himself qualified with feminine attributes. Teresa de Lauretis understands the system of gender identification as both a sociocultural 
construction and a semiotic tool, i.e. as a system of representation that ascribes specific signs to individuals within a particular group such as social class, sporting prowess, job type, etc. ${ }^{19}$ Problems appear to arise, then, when signs and their signification shift within a particular category, for instance when women leave the home and enter into the masculine workplace.

If the function of masculinity lies in the communication of social constructions, so these codifications find themselves mediated through different forms of cultural expression, from the press to film, from the internet to music. As signifying codes and operative fictions are propagated through different media, so the increased social exchanges allow for our understanding of such notions as masculinity to be moved forward. The articles presented here thus show how cinema (Marianne Kac-Vergne), men's magazines (Growse), the internet (Mélanie Gourarier), and pop music (Tinker) all participate in the production, reproduction, and sometimes disruption of certain myths and rituals of homosociality. Further, with new technology speeding up communication on a global scale and the development of new media allowing for a proliferation of messages targeting evermore sub-defined social groups, we can expect masculinity to continue pluralizing and fragmenting. The evolution of the 'buddy movie' genre studied by Kac-Vergne is exemplary in this respect, though the inclusion of AfroAmerican characters in such films, as Kac-Vergne demonstrates, is not necessarily as progressive as one might think and the racial bias of such movies needs to be questioned thoroughly.

Though these changes in the way we represent the notion of masculinity are a force for deconstruction, in this context the communication of masculinity itself necessarily becomes less and less stable. As Mike Featherstone demonstrates, the instability provoked by the globalisation of culture leads to a reaffirmation of more secure traditional values: "An increasing familiarity with 'the other' [...] may equally lead to a disturbing sense of engulfment and immersion. This may result in a retreat from the threat of cultural disorder into the security of ethnicity, traditionalism or fundamentalism [...]." ${ }^{20}$

This type of reaction serves to construct an ideology of nostalgia. Hence, in order to counter a sense of 'masculinity in crisis' provoked by an all-inclusive worldview, certain responses attempt to reconstruct a collective sense of identity at the local level. The availability of new media, however, means that the local need no longer be defined by a sense of place and can identify communities that share specific common interests across the planet like the virtual communities analysed by Gourarier. Attempts at social control through processes of reconstruction will never be able to stop manifestations of social non-conformity from emerging, and this is further underlined with the development of new media, as Hall explains: "New technologies today further complicate this dynamic as individuals no longer even need to be in physical proximity to find each other, discover common ground, and privately or publicly proclaim a shared identity." ${ }^{21}$

21 Thus, it becomes impossible to separate the global from the local; there is an intricate complex tension between the two that cannot be ignored. This phenomenon, whereby an ever more available worldview would lead to a 'retribalization', had already been identified by Marshall McLuhan in the 1960s. Having recognised the importance of what were to become new technologies, McLuhan spoke famously of the global village, 
where the worldwide communication of local cultures allows the individual to escape the conformity of society: Individual talents and perspectives don't have to shrivel within a retribalized society [...]

The tribe, you see, is not conformist just because it's inclusive; after all, there is far more diversity and far less conformity within a family group than there is within an urban conglomerate housing thousands of families. It's in the village where eccentricity lingers, in the big city where uniformity and impersonality are the milieu. The globalvillage conditions being forced by the electric technology stimulate more discontinuity and diversity and division than the old mechanical, standardized society; in fact, the global village makes maximum disagreement and creative dialog inevitable. ${ }^{22}$

In light of this, we must perhaps revaluate a sense of hegemonic masculinity as being simply prescriptive. Indeed, even the most hermetic totalitarian regime can be subverted through samizdats, irony and parody, armed resistance, silence. ${ }^{23}$ The articles presented here all contribute to the analysis of various strategies of resistance that media representations of male bonding resort to, subverting the very imagery they relied on for so long such as cross-dressing in pop music performances (Tinker), avatars in online communities (Gourarier), parody in buddy movies (Kac-Vergne), or ambiguity in men's magazines (Growse). In this way hegemonic masculinity may well have embedded in its very nature a propensity for crisis, as Connell suggests: "Hegemony, then, does not mean total control. It is not automatic, and may be disrupted - or even disrupt itself." ${ }^{24}$

Once again, if masculinity, hegemonic or otherwise, is not a rule imposed by a higher power but a social code that has been culturally defined and identified as the most common consensus then it is a product of its time that will necessarily evolve. Further to this, Connell reminds us that different media offer a stage for the performance of hegemonic masculinity, which then feeds back into society guaranteeing us the comfort of our own received ideas on gender practice:

26 At any given time, one form of masculinity rather than others is culturally exalted. Hegemonic masculinity can be defined as the configuration of gender practice which embodies the currently accepted answer to the problem of the legitimacy of patriarchy, which guarantees (or is taken to guarantee) the dominant position of men and the subordination of women [...].

This is not to say that the most visible bearers of hegemonic masculinity are always the most powerful people. They may be exemplars, such as film actors, or even fantasy figures, such as film characters. ${ }^{25}$

28 As the consensus on hegemonic masculinity shifts through time, so the representation of male heroes in Hollywood, for example, has moved from George Bailey to Rambo, from Obi-Wan Kenobi to Alan Garner. ${ }^{26}$ It is perhaps within the gaps provoked by the shifts in gender practice that the sense of crisis is created until the situation is once more stabilized and the new consensus rendered available as signifying codes through different media.

The term 'crisis' deserves significant attention especially if we are to escape trite uses of the much media-hyped expression that 'crisis of masculinity' has become. At one level, a crisis can be understood simply as a critical point that requires some form of resolution through decisive action. If the crisis is not resolved then a point of no return 
is reached. In Jürgen Habermas's early writings, crisis is understood as a means to political emancipation if responded to by a combination of decisive action and selfknowledge. Here, the idea of self-knowledge is crucial, relying on society's capacity, or indeed, on an individual's capacity, to be self-reflexive and thus relying on their ability to reveal to themselves the illusions that they have been harbouring about themselves. 27

As Habermas developed his theory on crisis, he engaged with systems theory. A system is a structure which draws on natural resources from its environment to transform them into a product (from consumer goods to the health service) and Habermas came to see a crisis as a failure in such a system. ${ }^{28}$ Concentrating on capitalist systems, for Habermas, crisis tendencies come to represent the potential for failure (from the absence of natural resources to strike action). For Connell, however, it is difficult to talk of a crisis of masculinity because masculinity itself is not a system. We must, therefore, return to the question of gender practice:

The concept of crisis tendencies needs to be distinguished from the colloquial sense in which people speak of a 'crisis of masculinity'. As a theoretical term 'crisis' presupposes a coherent system of some kind, which is destroyed or restored by the outcome of the crisis. Masculinity [...] is not a system in that sense. It is, rather, a configuration of practice within a system of gender relations. We cannot logically speak of the crisis of a configuration; rather we might speak of its disruption or its transformation. We can, however, logically speak of the crisis of a gender order as a whole, and of its tendencies towards crisis. ${ }^{29}$

Whether it is gender in general or more specifically masculinity itself within which crisis tendencies can be identified, we cannot negate the fact that the practice of gender or masculinity is performed by human beings. As Andrew Edgar underlines, however, "[s]ociety may be modelled as a system, but at the end of the day it is made up of real people making real decisions." ${ }^{30}$ A system cannot resolve its own failures, indeed, only people can identify crises through self-knowledge. In this way, when we read of a crisis of masculinity perhaps we must understand it as a failure of operative fictions within gender relations recognized as such and requiring decisive action for social codifications and practices to evolve.

\section{The Mediation of Male Bonds}

The much talked about crisis of masculinity could be qualified in part as a "crisis of representation'. ${ }^{31}$ Different forms of media representation contribute to this, acting, on the one hand, as a prism through which meaning is constructed and, on the other, as a mirror reflecting back into society a perceived form of reality. In this way, the media and mediated representations become the voice of authority that dictate and forbid certain social roles for men and performances of masculinity; they become the purveyors of the hegemonic masculinity of the time.

However, as we have seen hegemonic masculinity has built within it a capacity for change, and it contains crisis tendencies. As Hall insists, following on from Foucault, there is always a need "to multidimensionalize power relationships to resist reducing them to a simple top/down model of socio-sexual regulation." ${ }^{2}$ Indeed, the more hegemonic the system, the more threatening the resistance. Hegemonic masculinity, therefore, can only lead to new male bonds that attempt to redefine what is socially 
acceptable even if, as Hall reminds us, "paradigm shifts occur very slowly." ${ }^{33}$ As this introduction suggests then, different media representations continually confront us with a paradox that Chris Haywood and Máirtín Mac an Ghail identify as social problems seen through the eyes of "common-sense psychology":

On the one hand, media representations suggest that this 'what about the boys?' narrative, which they have been central in projecting, is a late modern(ity) phenomenon. On the other hand, they draw upon rather atavistic ideas - an amalgam of common sense and scientific theories - making appeals to an earlier imaginary gendered social order, based on biological differences between men and women. These images are accompanied by a nostalgic remembering of a 'golden past', when men and women occupied established gender roles in a stable social system.

The popular media script follows a familiar format in which particular social issues are selected: the absent father, the violent football fan or the underachieving male student, for example. ${ }^{34}$

The idea of "common sense-psychology" reminds us of the positivist strategy of gender characterisation which aims to offer an empirical categorisation of masculinity by defining men as what they actually are. As Connell points out, however, categorisation is a "process of social attribution using common-sense typologies of gender," 35 which means the system is based on assumptions and suppositions about masculinity. Rather than define what men are, the normative system attempts to portray men as what men 'ought to be'. In light of media representations this is perhaps the most prevalent system we have discussed, where the performance of masculinity corresponds to the social consensus. Here, exemplars such as film actors/characters, sportsmen, singers, are presented as and come to represent role models of masculinity.

The process of defining itself can be conceived as an exclusion procedure, the masculine being what is not feminine. This is how the semiotic strategy functions, as a system that attributes signs of symbolic value that attempt to differentiate between masculinity and femininity. This 'war of the sexes' system is very limited as it excludes from the equation relationships with other social systems, such as consumerism or war, and the effects of these systems on gender construction. Finally, the most commonly available signifying codes are born out of the essentialist strategy where certain behaviour traits and characteristics are held to be biological truths. In this way men are genetically programmed to buy technological gadgets and fight wars. It is this approach that provokes Robert De Niro's character, Jack Byrne, in the films Meet The Parents ${ }^{36}$ and Meet the Fockers ${ }^{37}$ to question whether his future son-in-law, nurse Gaylord Focker, is man enough for his daughter. Though this is a wry critique of reactionary attitudes towards masculinity, it is the approval of De Niro's portrayal of the father figure that is sought throughout the two films.

39 As the articles collected here show, beyond these strategies it is the relationships that men and women forge and the social interactions with which they engage that define their gender identities. Gender practice, both in performance and representation, is socially and culturally constituted through bonds that connect people together. In the words of Connell:

Rather than attempting to define masculinity as an object (natural character type, a behavioural average, a norm), we need to focus on the processes and relationships through which men and women conduct gendered lives. 'Masculinity', to the extent the term can be briefly defined at all, is simultaneously a place in gender relations, the 
practices through which men and women engage that place in gender, and the effects of these practices in bodily experience, personality and culture. ${ }^{38}$

Today, male bonds - from kinship to friendship, from the homosocial to the homosexual - continue to present an intriguing and complex multidisciplinary area of study that remains under-examined. If Judith Butler's principle that gender is performed holds true, then it becomes an important exercise to explore how media representations of these relationships between men feed into the performance of the relationships themselves..$^{39}$ Through different media these relationships come to be defined both by their performance and reception, changing the way male bonds are constituted and function in society. However, Butler's notion of performance also opens the possibility of playing with the norm, so that one is not bound to the values that certain media representations convey.

In film, buddy movies shift the focus from the traditional romantic male-female relationship toward heterosexual male comradeship allowing for explicit expressions of homosocial friendship. With the popularity of action movies in the 1980s a new crossover genre developed combining action and homosocial relationships producing such film franchises as $48 \mathrm{Hrs}^{40}$ and Lethal Weapon, ${ }^{41}$ where idealized images of the male hero are offset by expressions of a masculinity in crisis. Parallel to this, or perhaps as a reaction to this, science fiction action movies came out of Hollywood portraying what Marianne Kac-Vergne calls 'hypermasculine' male machines that are invincible and invulnerable. With the emergence of biracial buddy movies from the 1970s onwards, Kac-Vergne asks if hypermasculinity can be seen as "the aggressive concretization of hegemonic masculinity, the reassertion of the white man's superiority in Reaganite America".

In the written press, the popularity of men's magazines, or 'lads mags', may have done much to transfer attention away from the notion of the caring sensitive 'new men' by trying to make expressions of chauvinism acceptable, but they also gave space to articles on such topics as men's health and fatherhood, therefore, recognizing a change in how certain men viewed themselves as individuals and consequently recognizing a change in how they viewed the male groups to which they belong. Nick Growse studies the representation and reception of masculinity in different categories of men's magazines and observes that if in continental Europe such publications portray men as healthy and sporty, these images are rejected by the British male audience as 'unmanly'. Growse identifies a paradox in British men's magazines where "the representation of masculine weakness is generated by men for male consumption". Through a number of case studies, Growse demonstrates that the discourse of these 'lads mags' creates a community of male readers that positions itself as a resistance to the dogma of hegemonic masculinity.

The Internet has served to accelerate how male bonds are defined and redefined, asserted and reasserted. Online communities have moved the concept of societies from the local to the global allowing for an unprecedented upscaling of potential affinities. This has allowed for the once negatively-viewed societal status of being a 'geek' to be given a public forum, whereas, conversely, some online communities that focus on male sexual prowess have preferred to retire behind private fee-paying portals. In both cases, however, the collaborative nature of Web 2.0 allows for peer-review on a global scale which may lead to mass recognition or mass humiliation. As Mélanie Gourarier demonstrates, though the medium has changed, perhaps here we still find practices of 
male bonds that continue to construct frameworks that ensure male domination, not over women, but over subordinated masculinities.

Simon Reynolds has argued that pop music has developed an obsession with its own past and the popularity of musical nostalgia tours bear witness to this. ${ }^{42}$ According to Chris Tinker, the re-emergence of artists promoting the music that made them famous a generation ago appears to have created a new space for 'midlife masculinities' to express themselves. Here, masculinities appear to be performed knowingly, as if the passing of time has afforded these male artists the distance necessary for social reflexivity. This has allowed such pop stars of the 1980s as Boy George, Jason Donovan and Rick Astley, to escape characteristics traditionally attributed to hegemonic masculinity, such as aggression, domination and heterosexuality, and challenge the discourse of midlife maturity "through the importance attached to emotion and sensitivity, a reduction in work related competitiveness and the expression of a more detached, light-hearted, even flippant, attitude".

This special issue follows on partly from the international conference Performing the Invisible: Masculinities in the English-Speaking World, organized at the Université Sorbonne Nouvelle-Paris 3 on September 25-26, 2010 (http://www.men.univ-paris3.fr) and sponsored by the university's research groups CREW and PRISMES, its postgraduate school EDEAGE-Etudes Anglophones, Germanophones et Européennes, its research council and its division for international relations. The conference was part of the two-year transdisciplinary research project Performing Straight White Masculinities, sponsored by the Sorbonne Nouvelle's research council. The editors of this special issue wish to thank the conference's organizing committee, namely Ariane Blayac, Sophie Chapuis, Claire Conilleau, Claire Delahaye, Marianne Kac-Vergne, Marie Moreau, Emilie Piat and Hélène Quanquin.

\section{BIBLIOGRAPHY}

Butler, Judith. Gender Trouble: Feminism and the Subversion of Identity. London: Routledge, 1990.

Cixous, Hélène and Catherine B. Clement. La jeune née. Paris: Union Générale d'Editions, 1975.

Clare, Anthony. On Men: Masculinity in Crisis. London: Random House, 2000.

Connell, R.W. Masculinities. Cambridge: Polity, 2005.

De Lauretis, Teresa. The Technologies of Gender: Essays on Theory, Film and Fiction. Bloomington: Indiana University Press, 1989.

Dudink, Stefan. “The trouble with men: Problems in the history of 'masculinity"'. In European Journal of Cultural Studies 1 (1998): 419-31.

Edgar, Andrew. Habermas: Key Concepts. Abingdon: Routledge, 2006.

Featherstone, Mike. Undoing Culture. London: Sage, 1995. 
Grant, C. B. Literary Communication from Consensus to Rupture. Theory and Practice in Honecker's GDR. Amsterdam/Atlanta (GA): Rodopi, 1995.

Grant, C. B. "Probleme des Öffentlichkeits-Begriffes im Verorten von Literatur." LUMIS-Schriften University of Siegen 45 (1996): 20pp.

Habermas, Jürgen. Theory and Practice. Translated by John Viertel. Boston, MA: Beacon Press, 1976 (1971).

Habermas, Jürgen. Legitimation Crisis. Translated by Thomas McCarthy. London: Heinemann, 1976 (1973).

Halberstam, Judith. Female Masculinity. Durham: Duke University Press, 1998.

Hall, Donald E. “Gender and Queer Theory”. In The Routledge Companion to Critical Theory, edited by Simon Malpas and Paul Wake, 102-14. Abingdon: Routledge, 2006.

Haywood, Chris and Máirtín Mac an Ghail. Men and Masculinities. Buckingham: Open University Press, 2003.

Kimmel, Michel S. "Invisible Masculinity”. Society 30, no. 6 (1993): 28-35.

McLuhan, Marshall. “The Playboy Interview: Marshall McLuhan.” Playboy Magazine, March 1969, http://www.mcluhanmedia.com/m_mcl_inter_pb_03.html.

Meet the Parents. Dir. Jay Roach. Perf. Robert De Niro, Ben Stiller, Teri Polo, Blythe Danner, and Owen Wilson. United States: Universal, 2000.

Pease, Bob. Recreating Men: Postmodern Masculinity Politics. London: Sage, 2000.

Reynolds, Simon. Retromania: Pop Culture's Addiction to Its Own Past. London: Faber, 2011.

Rotundo, E. Anthony. American Manhood: Transformations in Masculinity from the Revolution to the Modern Era. New York: Basic Books, 1993.

Schaper, Eva. "The Kantian Thing-in-Itself as a Philosophical Fiction". The Philosophical Quarterly 16, no. 64, History of Philosophy Number (July 1966): 233-43.

Simon, William. Postmodern Sexualities. London: Routledge, 1996.

Solomon-Godeau, Abigail. Male Trouble: A Crisis in Representation. New York: Thames and Hudson, 1999.

Whitehead, Stephen M. "Men”. In International Encyclopedia of Men and Masculinities, edited by Michael Flood, Judith Keegan Gardiner, Bob Pease and Keith Pringle, 401-05. Abingdon: Routledge.

Žižek, Slavoj. The Plague of Fantasies. London: Verso, 2008.

\section{NOTES}

1. Michael S. Kimmel, "Invisible Masculinity," Society 30, no. 6 (1993): 28.

2. Stephen M. Whitehead, "Men," in International Encyclopedia of Men and Masculinities, eds Michael Flood, Judith Keegan Gardiner, Bob Pease and Keith Pringle (Abingdon: Routledge, 2007), 402.

3. Judith Butler, Gender Trouble: Feminism and the Subversion of Identity (London: Routledge, 1990), 25.

4. Butler, Gender Trouble, 33. 
5. OED Online, June 2012, s.v. “masculinity, n.”, http://www.oed.com/view/Entry/114566? redirectedFrom=masculinity (accessed August 27, 2012).

6. For further reading see Judith Halberstam's Female Masculinity (Durham: Duke University Press, 1998).

7. R.W. Connell, Masculinities (Cambridge: Polity, 2005), 67.

8. Within the context of this definition, it is important to note that there are cases of transgender men who, having retained a functioning womb and ovaries, have given birth.

9. OED, s.v. "manliness, n." http://www.oed.com/view/Entry/113556?redirectedFrom=manliness (accessed August 27, 2012).

10. Donald E. Hall, "Gender and Queer Theory," in The Routledge Companion to Critical Theory, eds Simon Malpas and Paul Wake (Abingdon: Routledge, 2006), 103.

11. Anthony E. Rotundo, American Manhood: Transformations in Masculinity from the Revolution to the Modern Era (New York: Basic Books, 1993), 7.

12. See Connell, Masculinities.

13. Stefan Dudink, "The trouble with men: Problems in the history of "masculinity", European Journal of Cultural Studies 1 (1998): 425.

14. Hall, "Gender and Queer Theory," 106.

15. Hélène Cixous and Catherine B. Clement, La jeune née (Paris: Union Générale d'Editions, 1975).

16. Anthony Clare, On Men: Masculinity in Crisis (London: Random House, 2000).

17. Clare, On Men, 6.

18. William Simon, Postmodern Sexualities (London: Routledge, 1996), 94.

19. Teresa De Lauretis, The Technologies of Gender: Essays on Theory, Film and Fiction (Bloomington: Indiana University Press, 1989).

20. Mike Featherstone, Undoing Culture (London: Sage, 1995), 91.

21. Hall, "Gender and Queer Theory," 104.

22. Marshall McLuhan, "The Playboy Interview: Marshall McLuhan," Playboy Magazine, March, 1969, http://www.mcluhanmedia.com/m_mcl_inter_pb_03.html (accessed August 6, 2012).

23. For further reading see Colin B. Grant's Literary Communication from Consensus to Rupture. Theory and Practice in Honecker's GDR (Amsterdam/Atlanta (GA): Rodopi, 1995) and "Probleme des Öffentlichkeits-Begriffes im Verorten von Literatur." LUMIS-Schriften University of Siegen 45 (1996).

24. Connell, Masculinities, 37.

25. Connell, Masculinities, 77.

26. These are characters respectively from It's a Wonderful Life (Frank Capra, 1946), First Blood (Ted Kotcheff, 1982), Star Wars (George Lucas, 1977) and The Hangover (Todd Philips, 2009).

27. Jürgen Habermas, Theory and Practice, trans. John Viertel (Boston, MA: Beacon Press, 1976a (1971)).

28. Jürgen Habermas, Legitimation Crisis, trans. Thomas McCarthy (London: Heinemann, 1976b (1973)).

29. Connell, Masculinities, 84.

30. Andrew Edgar, Habermas: Key Concepts (Abingdon: Routledge, 2006), 31.

31. See Abigail Solomon-Godeau's Male Trouble: A Crisis in Representation (New York: Thames and Hudson, 1999) for an analysis of how representations of the masculine ideal in $18^{\text {th }}$ and $19^{\text {th }}$ century art influenced the male public of the time and continue to influence our conception of masculinity today.

32. Hall, "Gender and Queer Theory," 104.

33. Hall, "Gender and Queer Theory," 104.

34. Chris Haywood and Máirtín Mac an Ghail, Men and Masculinities (Buckingham: Open University Press, 2003), 146.

35. Connell, Masculinities, 69.

36. Meet the Parents (Jay Roach, 2000). 
37. Meet the Fockers (Jay Roach, 2004).

38. Connell, Masculinities, 71 .

39. Judith Butler, Gender Trouble: Feminism and the Subversion of Identity (London: Routledge, 1990).

40. 48 Hrs (Walter Hill, 1982).

41. Lethal Weapon (Richard Donner, 1987).

42. Simon Reynolds, Retromania: Pop Culture's Addiction to Its Own Past (London: Faber, 2011). 